\title{
KANT'S CONSTITUTION OF A MORAL IMAGE OF THE WORLD*
}

\author{
Joel Thiago Klein** \\ https://orcid.org/0000-0003-2665-9113 \\ jthklein@yahoo.com.br
}

\begin{abstract}
In this paper, I argue that the idea of a universal history is systematically legitimized in Kant's transcendental system of philosophy by way of the concept of a need [Bedürfnis] for pure practical reason. In this sense, the idea of a universal history is a fundamental part of the moral image of the world that emerges from Kant's whole philosophy, and it is crucial for understanding both the possibility of the system of pure reason, as well the full development of Kant's moral philosophy, especially for political philosophy.
\end{abstract}

Keywords Reason, Universal History, Need, Highest good.

RESUMO Nesse artigo eu argumento que a ideia de uma história universal é sistematicamente legitimada no sistema da filosofia transcendental de Kant por meio do conceito de precisão [Bedürfnis] da razão pura prática. Nesse sentido, a ideia de uma história universal é uma parte fundamental da imagem moral do mundo que emerge da totalidade da filosofia de Kant é crucial para o entendimento tanto da possibilidade de um sistema da razão pura, quanto para um desenvolvimento completo da filosofia moral, particularmente para a filosofia política.

Palavras-chave Razão, História Universal, Precisão, Sumo bem.

* Artigo submetido em 11/01/2018 e aprovado em15/03/2018.

** Universidade Federal de Santa Catarina - UFSC. Florianópolis, SC, Brasil. Bolsista produtividade CNPQ. 
To systematically legitimize Kant's philosophy of history, much more is needed than the guarantee of a lack of contradiction between the different parts of the system. ${ }^{1}$ Nor is it enough to establish a simple connection between universal history and some transcendental principle, because this link could always be seen as merely a systematic indication, while not yet achieving the status of an argument for its inclusion within the transcendental system. If the latter had not been demonstrated, then Kant's work on the philosophy of history might always have been seen to hold only historical and cultural interest, but it would have remained as a mere appendix to his philosophical system and it could have been simply disregarded at will. ${ }^{2}$

Thus, the legitimacy of universal history itself depends on its articulation within the architectonic of pure reason, i.e., it must be demonstrated that it "arises only in consequence of an idea (where reason provides the ends a priori and does not await them empirically)". In this case, it must be shown that universal history is part of the systematic unit of reason that has already been determined a priori, according to the concept of an articulated whole. That is exactly the purpose of this paper, which unfolds in five sections. In the first segment, Henrich's notion of the moral image of the world is presented as the guiding thread for our reading. The second and the third parts argue that universal history is linked to a moral image of the world by way of the concept of an "extended moral consciousness" that is grounded in the need of pure practical reason. In the fourth section, it is shown that the idea of a universal history is a condition of possibility for reason to see itself as completely systematic. Finally, the last part extends the consequences of this reading into the realm of Kant's political philosophy.

\section{The concept of the moral image of the world}

According to Henrich, the concept of "image of the world" is inherent to Kantian philosophy. It is legitimized based on certain mental operations and is used in certain contexts (Cf. Henrich, 1992; Düsing, 1968, p. 229ss.). On the horizon of critical-transcendental philosophy, this means that one can meet or establish a priori a certain image of the world. In the case of the theory of knowledge, this image is necessary to the extent that it is a condition of possibility for the very unity of self-awareness. Thus, one can understand why such a worldview is natural, indispensable and theoretically legitimate for us.

1 A Portuguese version of the thesis that I develop here can be found in my book Klein (2016a).

2 I want to thank Rolf-Peter Horstmann for drawing this challenging question to my attention. 
The same reasoning would also apply in the field of ethics. In this case, there is the notion of a "moral image of the world". It corresponds to a set of beliefs that are inseparably linked to the perspective of the moral agent and which are coherently linked into a single conceptual network. However, there may be contrasting moral images of the world, but a morally enlightened individual can only have one single moral image, which must satisfy two criteria: 1) it must be able to incorporate other images of the world without allowing the arising of anarchy between them; and 2) this moral image must be able to survive other competing moral images, that is, it must remain reasonable and immune to criticisms of arbitrariness and irrationality and maintain a certain centrality and superiority over other competing moral views. Once it has satisfied these two criteria, one can speak of a "moral worldview", in the singular.

Henrich also posits that, when all three Critiques are taken together, they seek, by way of studying the various rational discourses and their origins, to provide an answer to the question of what this "moral image of the world" might be, as it is understood in the singular. So, the passage where Kant says that he had to "limit[ing] knowledge in order to make room for faith", should be read in such a way that "faith" represents nothing more than the content of the moral image of the world.

Therefore, following Henrich's suggestion, we should be able to demonstrate that the philosophy of history has a necessary place in the system of Kant's philosophy to the extent that the idea of a universal history was a necessary component of the "moral image of the world" according to critical-transcendental philosophy. However, this should be arrived at through transcendental deduction, which means that it must explain how the idea of a universal history could be a condition of possibility for a certain aspect of self-awareness that is understood as a priori. This means that the philosophy of history could be guaranteed to fit into the system of pure reason, so long as it is made clear that the idea of a universal history is a necessary component of the very system of pure reason. In other words, one has to show that, without the idea of a universal history, reason itself could not be seen to be completely systematic and, could not, therefore, be reason. Again, we must demonstrate that universal history is the condition of possibility of a rational self-understanding of reason itself. This will be attempted here, defending the thesis that the idea of universal history is founded upon the right of practical reason to expand its power in order to produce a broad practical reflection.

The following argument will be divided into three stages, each one in a specific following section: 1) contrary to Henrich's position, it is argued that, in the context of Kantian practical philosophy, the moral self-awareness of the 
individual can be necessarily bound up with a moral image of the world without harming the autonomy of will; 2) the universal history will be shown to be a necessary element of that moral image of the world, which also 'reflects' the system of reason; and 3) brief consideration regarding the nature of reason and the justification of universal history will be presented.

\section{The concept of an expanded moral consciousness}

According to Henrich, there are two ways in which a moral image of the world might be related to moral consciousness. The first form is when moral consciousness is complete in and of itself and does not need a moral image of world. In this case, the moral image of the world arises only when that consciousness is exposed to questions and criticisms; the creation of a moral image only serves as a defense of its moral integrity. This link may be spontaneous and it needs not to be mediated by philosophical speculation. It is, however, still a set of beliefs that arise from the needs of consciousness, which is to say that reason works in alliance with moral interest. The second form is when the moral image and moral consciousness come together as a single and indivisible complex, like consciousness and its consequence. In this case, there are only two things for a philosopher to do, namely: analyze and understand the structure of the moral image as it emerges from the moral perspective and, secondly, to justify morality and the moral image against criticisms about its alleged illusion. In this case, justification is always attributed simultaneously to moral consciousness and moral image (Cf. Henrich, 1992, p. 11ss.).

Henrich posits that Kant's philosophy fits into the second model, that is, the moral consciousness must be understood to arise simultaneously with the moral image of the world. This would be the case even with his definitive moral model in the $C \operatorname{Pr} R$. However, based on the doctrine of the fact of reason, Kant would have some difficulties in explaining why both should remain together. After all, the sentiment of respect becomes the sole motivation [Triebfeder] for good will. Thus, Henrich argues, Kant would have maintained the link between moral consciousness and the moral world image without justifying it and only due to the profound influence of Rousseau's philosophy (Cf. Henrich, 1992, p. 24). Having realized this problem, Kant would have tried to solve it in $C J$ by resorting to various concepts of purposiveness. However, Henrich reasons that Kant never felt satisfied and that is why he continued to work on the topic for the rest of his life without ever coming up with a definitive solution. Besides it was in the $R G V$ that he first put this problem in terms of an a priori synthetic judgment. 
Henrich's analysis is quite sharp, and provides an important and clear conceptual framework that will underlie the following passages to some extent. However, I fundamentally disagree with him on two counts. Firstly, the relation of the highest good to moral law presents itself as an a priori synthetic judgment as early as in $\operatorname{CPr} R$. Secondly, it is argued here that there are not merely two, but also a third way in which moral consciousness can be connected to a moral image of the world.

The third model, which was not taken into account by Henrich, refers to a connection between moral consciousness and the moral image of the world that does not depend on a direct and immediate link between moral law (moral consciousness) and the highest good (the moral image of the world). Neither does it refer to a randomly proposed mediated link, as if moral consciousness were feeling pressure from some external criticism or by some competing moral images of the world. In other words, according to Henrich, the moral image of the world either comes immediately with moral law as if they were one, or it emerges as a useful fiction that is needed to convince oneself of the reality of moral law when moral consciousness is under some form of attack (cf. Henrich, 1992, p. 25). A third model would be an indirect yet necessary connection between moral law and the highest good (or between moral consciousness and the moral image of the world). It would not arise from moral law itself nor from any external or contingent needs, but instead from a specific and proper need of pure practical reason. In other words, it would arise from the need for a more comprehensive intentionality of reason as a faculty which takes in and articulates various types of mental operations.

In Kant's works on practical philosophy, the moral consciousness has two levels of intentionality, like two layers from which will projects itself. The first one is where will is exercised in a determinant way which is inscribed within the concept of good. At this level, consciousness is objectively actualized in the intentionality of actions, but it cannot fully actualize its object in experience, i.e., in the effects of actions. In other words, Kant's moral theory of respect for moral law determines the aim of the action, but only up until the concept of good. The effects of the action, that is, what is phenomenally triggered by the act, remains out of the scope of the determination of that consciousness. Even so, will is understood as good and as being made sufficiently effective, to the extent that the moral law is the motive for the action. In this sense, "A good will is not good because of what it effects or accomplishes, because of its fitness to attain some proposed end, but only because of its volition [...]. Usefulness or fruitlessness can neither add anything to this Worth nor take 
anything away from it" (GMS, AA 04, 394. 13-16; 26-27). ${ }^{3}$ This first level of the moral consciousness can be called the strict sense of moral consciousness.

However, practical reason intends to transcend this first level of intentionality. It wants to project its field of action beyond the determination of the maxim. After all, it is not "a mere wish but as the summoning of all means insofar as they are in our control" (GMS, AA 04, 394. 23-24). But despite its intention, practical reason cannot exceed the inherent limit of the will of a rational finite being. This inability does not make it indifferent to what happens beyond those limits. This is shown when we consider what would happen to moral consciousness if it represented itself as a part of a world in which its intentionality was absolutely restricted within that first level, namely, the idea of a moral consciousness would collapse if the moral individual had to believe that all moral actions had effects that prevented their goals from being realized. In other words, if moral consciousness should think of itself as a part of a world ruled by an evil genius (rather than as a nature that just did not care about moral ends), then rationality would collapse into itself and moral action would become meaningless (Cf. $K U$, AA 05: 471n. Also in TP, AA 08: 309. 14-17). This shows that reason really "wants" and needs (has a Bedürfnis) to exceed its first level of moral consciousness and transform the world according to its practical normativity. However, consciousness also knows that not only is it unable to obtain any guarantee but that no guarantee is necessary. After all, it knows that "it can, because it should". Practical reason can only exceed these limits by giving up the determinant character of its intentionality.

The second level of moral consciousness does not come directly and immediately from the very consciousness of the moral law. "[T]hus it is also not meant to say that it is necessary to assume the happiness of all rational beings in the world in accordance with their morality for morals, but rather that it is necessary through their morality" (KU, AA 05: 451n.). This formulation represents a step out of the domain of moral consciousness in strict sense. At this second level, the intentionality of consciousness is no longer restricted to the moral determination of the action, but it seeks the effects, which, in turn, are not required for the first level of consciousness, even if it is not indifferent to them. Still, there is a link between them, because the first level of moral consciousness always works as a condition of possibility for the second. We can call this second level an expanded moral consciousness.

3 All translations of Kant's works are quoted from The Cambridge Edition of the Works of Immanuel Kant and follow the system established by the Akademie Ausgabe. 
Although expanded moral consciousness has moral consciousness as a condition, one does not simply arise from the other, otherwise they would simply be one and the same. Intentionality differs at each level. It is determined intentionality at the first level and a merely reflective one at the second. At the first level, moral action is carried out in response to a commandment, a law, while, at the second, the action is contextualized and interpreted because there is a need (Bedürfnis) of pure practical reason: "As pure practical reason it likewise seeks the unconditioned for the practically conditioned (which rests on inclinations and natural needs), not indeed as the determining ground of the will, but even when this is given (in the moral law), it seeks the unconditioned totality of the object of pure practical reason, under the name of the highest good" (KpV, AA 05: 108).

This expanded moral consciousness is not strictly moral, but it is practical. It neither presents another moral law, nor does it introduce a new aspect of the law. Therefore, it does not add in a strict sense any constitutive element for practical philosophy. Hence, it does not essentially belong to the core of the Metaphysics of Morals, that is, as a constitutive part of it. In other words, there is no special commandment regarding the highest good, ${ }^{4}$ which is not the object of the will, ${ }^{5}$ although it is the object of the entire pure practical reason.

This practical character of the expanded moral consciousness, which is not moral in a strict sense, refers to reason's intention to understand itself as an 'organism' in which all its faculties intend to accomplish something that ultimately needs to be put together. For pure reason does not see itself as "schizophrenic", it is not enough that its different uses are noncontradictory. It must understand them as integrated and belonging to the same self. What the "self knows" and what the "self must do" need to be integrated, so that both activities are fostered according to a moral image of the world which covers and articulates both uses in the field of what the "self may hope". However, this promotion depends on both activities finally converging to the same point, otherwise their individual efforts nullify the possibility of extended use.

4 Beck (1960, p. 244s.), in his critique of Silber (1959), makes this point very clear: either there is no imperative regarding the highest good (in the sense that is anything distinct from moral law), or we have lost the autonomy of will. For a detailed analysis of the distinction between the concepts of good and the highest good see my paper Klein (2016b).

5 This is, for example, the interpretation of Silber (1959), who states that the highest good is the necessary material object of the will and constitutes an answer to "what should I do?" Lebrun (1986) also argues for the existence of a necessary and consequent link between moral law (autonomy) and the highest good. Guyer (2000, pp. 385-390), despite posing a series of considerations, also takes the highest good to be the object of moral will. 
When one speaks of an expanded moral consciousness and its relation to the ideal of moral wisdom, it needs to be made clear that the status of that consciousness cannot be the same as the moral consciousness in a strict sense. If this is immediate and objective, that is mediating and reflexive. What does this mean? Firstly, similarly to moral consciousness, this expanded moral consciousness cannot be restricted to any empirical and contingent context. It must be able to be universally extended. In this sense, one cannot say that the possibility of extending practical intentionality is restricted to certain actions and not to others, nor to certain kind of finite beings and not to others. It cannot be limited to include some individuals or peoples and not others, nor can it take place at some times and not others. Moreover, when it comes to thinking about the possibility of an expanded use of the faculties, such use must be rational and therefore universal. Secondly, unlike the case of the first level, this increased moral consciousness is based on a subjective principle of pure reason (a need [Bedürfnis] of pure practical reason). ${ }^{6}$ This principle is also essentially practical, because the ultimate end of reason is practical. This is to say that the ultimate end of reason must be the realization of its own and more active form, in other words, to act upon the world. This is a subjective and practical principle, so the subsequent moral image of the world is not determinant. The highest good also appears in this reflection only as a reference point, which the subject can indefinitely approach by way of actions. This means that the systematic unity of reason cannot be proven. It is just a subjectively necessary presupposition, a maxim of reason, which enables the idea of a continuous and endless approximation to the moral image of the world. We can say that the actualization of the moral image of the world can be seen as a reflex of an expanded moral consciousness.

This shows why what we call a second level of consciousness does not require a third or a fourth level. The second level of moral self-consciousness extends indefinitely and will always be under construction (Kant sometimes uses the concept of a "task" (Aufgabe). Nevertheless, it is not a misguided growth, because the concept of the highest good, be it political or moral, functions as a building frame, a practical regulative idea. In this sense, the highest good is always a concept for projecting unity, which will never indicate a completed concept of a given unit. In other words, the moral image of the world does not postulate that humans at some point will achieve full compliance with the moral laws. Rather, it sustains that the people subordinated to moral laws are able to indefinitely approach such an ideal by way of their own efforts, thereby 
making the moral image of the world real and continuously strengthening the systematic unity of reason (cf. $K U$, AA 05: 446).

Although Kant always makes reference to 'pure practical and legislative reason', something that might suggest an immanence of the highest good in moral consciousness, he also always stresses that this is in regard to a broader concept of morality which comes about due to the concept of moral need. In order to avoid ruining the whole project of moral autonomy, this moral need can only be understood in the context of pure reason in its expanded use, namely, as a subjective need to achieve a complete system of practical purposes, that is, until the ultimate end is reached (when it arrives at a perfect systematic unity of reason) (cf. $\mathrm{KrV}, \mathrm{B}$ 868). Interpreting this need of pure practical reason as arising outside the scope of the first level of moral consciousness is the only way to ensure both the autonomous grounds for morality and the legitimacy of a moral image of the world.

This third form, which was not mentioned by Henrich, seems to be a legitimate reading due to the existence of consistent textual supports. Moreover, it is in accordance with the main theses and the design of Kant's system of philosophy. So, if moral consciousness in a strict sense is guided by the principle that 'I can do because I ought to do' (Cf. $K p V$, AA 05: 30), expanded moral consciousness is guided by the maxim of pure practical reason 'I believe because I need to.'

\section{The idea of a universal history as part of an expanded moral consciousness}

Expanded moral consciousness is not something given a priori, nor is it based immediately on the factum of moral law. It is bound to a legitimating fact which is only subjectively necessary - the need of pure practical reason. In fact, the expanded moral consciousness has as the concept of highest good a reference that guides its reflection and the process of adding content. However, if one imagines the concept of highest good from the individual perspective, then its content cannot be filled in, as this would go beyond the legitimate limits of all reflection, i.e., it is something which supposes concepts of an afterlife and an afterworld. This does not mean that in this context the concept of highest good is illegitimate, but that, as a reference, it has no potential to establish any more content for expanded moral consciousness (cf. $S F$, AA 07: 43f.).

So, the only way to provide any reflexive content to moral consciousness through the notion of highest good is by applying it to the context of the human species. When one thinks of the moral image of the world as a systematic link 
between nature and freedom, the relationship must always be seen in terms of legality, in such a way that it is possible to represent not only what is logically and transcendentally possible, but also how the actualization of freedom in nature is potentially a real possibility. In other words, we cannot conceive of the actualization of a moral purpose in the world, at least not in a casuistic manner, based on some specific sociocultural context. If there were a theory that allowed one to think of a link between freedom and nature, it would have to be rational and universal, even if only subjectively necessary.

For Kant, this mediation can only be brought about through the concept of moral teleology, which is legitimated by the need for pure practical reason and by the concept of a moral and wise God. From these concepts, it is possible to represent both a universal history and moral anthropology. In this sense, one can say that the moral image of the world in Kantian philosophy is made possible while universal history and moral anthropology ${ }^{7}$ become the means by which the teleological reflection adds content to expanded moral consciousness. Expressed in this way, "moral image of the world" and "expanded moral consciousness" are not quite the same. The moral image of the world is a far broader concept, because it also includes several theoretical and aesthetic elements that cannot be seen as directly linked to the field of human action, but only indirectly. So, the moral image of the world can also encompass physical teleology and the aesthetic theory, which surpass the expanded moral consciousness, because the latter assumes a practical intentionality, namely, it implies elements which are related to willing and acting.

It is important to take note of the fact that the practical reflective procedure that constitutes expanded moral consciousness serves as a basis from which to construct or to project an inter-subjective form of historical consciousness. Intersubjectivity is understood here in two ways: firstly, it depends on the intersubjective experience to be created; secondly, it can be shared by all human beings, that is, it is achievable and understandable as anyone's moral experience. Expanded moral consciousness is created in an inter-subjective fashion, because it is produced by the rational discourse that arises from the freedom of the public use of reason. This can be seen in Kant's analysis of the meaning of the Enlightenment and the French Revolution, for example. When some event brings up an important moral concept that 'will never be forgotten', it means that it has taken root in an intersubjective discourse of the public use of reason,

7 Moral anthropology is understood here as a part of pragmatic anthropology (as knowledge "of what man makes of himself, or can and should make of himself while a being who acts freely" (Anth AA 07: 119) and it is particularly linked to the faculty of desire. 
or that it has been embraced as a content of expanded moral consciousness. On the other hand, this event itself would not be a content of this consciousness if it were not subject to being accessed and shared by different people, in differing historical moments and distinct geographical and social contexts. This ability to share historical experience as moral content is what allows us to think that humanity can make progress, since said progress also means learning from mistakes and improving upon accumulated experience. One can only learn and improve from the mistakes of others if there is something that can be shared. In this sense, historical learning itself depends on the possibility of expanded moral consciousness. ${ }^{8}$

In the essay Conjectural Beginning of Human History, Kant is not trying to legitimize what has happened, nor is he proclaiming some sort of historical determinism. His point refers to the question of the recognition of an intersubjective responsibility, i.e. the production of content to the expanded moral consciousness that, due to its inter-subjectivity, can be attributed to the whole human species. In this sense, human beings must recognize for themselves some sort of responsibility for actions at an inter-subjective level. In other words, the successes and mistakes of past generations and even those of other people are also, in some sense, our successes and our mistakes. We need learn from the mistakes and successes of past generations and need acknowledge their success and failures as our own, thereby reading the actions of human history in a horizon of an expanded historical sense. We cannot and should not judge historical facts from an external perspective, as if we were above or outside history, because we are also always judging ourselves. This is the sense in which we should interpret Kant's famous assertions that "Enlightenment is the human being's emergence from his self-incurred minority" (WA, AA 08: 35. 01-02) and that, for Nature, rational man's self-esteem matters more than the well-being he can achieve (cf. IaG, AA 08: 20. 02-09).

Expanded moral consciousness provides the foundation for moral teleology and, thus, for the idea of a universal history. From another perspective, universal history becomes a source of empirical content for that consciousness, i.e., it can be seen as the very extended moral consciousness that is externalized in a rational discourse. To a certain extent, extended moral consciousness provides the formal condition for the universal history, while the universal history supplies the material condition for thinking the actualization of the extended moral consciousness. In some sense, expanded moral consciousness turns out to be 
essentially historical. Without the form of an expanded moral consciousness, the universal history would not have a priori concepts and principles, therefore, the historical data would simply be accumulated as a large clump or aggregate of facts that are rationally unrelated (despite being causally related), which merely leaves "dead weight" for future generations (cf. IaG, AA 08: 30f.). The need to turn the aggregate of human events into a system (cf. IaG, AA 08: 29. 13-16.) is nothing more than the rational practical need to transform mere facts or empirical data into contents of an expanded moral consciousness, while the concept of Nature, or Providence that "guides" history, works as its scheme. On the other hand, without the content provided by the narrative of universal history, expanded moral consciousness would be an empty consciousness. ${ }^{9}$

Something similar happens, mutatis mutandis, with historiography, which is to say that, since the events of ancient history have not been authenticated by the "historiography" of an "illustrated public", they are simply terra incognita (cf. $I a G$, AA 08: 29n.). In the same way, if the morally relevant experiences of humankind are not integrated into a universal history and therefore are not made into contents of an expanded moral consciousness, then they cannot be taken as moments of self-assessment, self-judgment and self-guidance which are presupposed in a moral image of the world that has a coherent cosmo-political action. Otherwise, they cannot be considered as the moral experience of humankind and, therefore, subjects cannot take them as their own experiences. In this sense, a universal history is the essential means by which moral consciousness gains empirical content and specificity.

One could also say, in comparison with Biology, that universal history has, mutatis mutandis, the theoretical status of a regulative knowledge. Neither discipline can objectively prove their assumptions, namely, the notion of teleological causality. However, one cannot forego the use of this "methodological knowledge" unless all judgment is abdicated. This, in turn, can only occur under the illegitimate assumption of a maxim of empiricist thinking that is completely distinct from a true knowledge of the limits of reason (cf. $\mathrm{KrV}$, B 795f.). If reason needs to extend its rationality over a field of empirical objects (in this case the historical data) and if it has the legitimacy to do so, there are no grounds for preventing this expansion, since it takes place in a way that respects the limits that reason has imposed on itself through transcendental reflection. Moreover, denying reason the right to act on a field where it has legitimacy to do so, only leaves room for "ghosts of the mind [Hirngespinsten]"

9 We can draw an analogy here with Kant's famous saying, "Thoughts without content are empty, intuitions without concepts are blind" (KrV, B 75). 
(cf. $K U$, AA 05: 411.26). In other words, in the same way that the knowledge of nature cannot incorporate teleological explanations, universal history is not part of the practical knowledge in a strict sense, i.e., it is not based on moral commandments, nor does the freedom of choice depend on the possibility of universal history.

So, universal history has no part in moral consciousness in the strict sense (the first level of moral consciousness). However, once there is a need or a practical interest on the part of reason to search out some sense in the aggregate of human events, then the only rational way to do so is by using a principle that arises from pure practical reason. Moreover, to deny the right of practical reason to build itself an extended moral consciousness only leaves it in a limbo of irrationality, which will be gradually populated by ghosts of the mind that can, if not destroy, at least erode moral consciousness in the strict sense.

Therefore, universal history is the condition of possibility for allocating empirical content to extended moral consciousness, which is not merely an element that develops naturally from pure practical reason; it is also something already present in the discourse of common understanding and it is a condition for our self-understanding as historical beings. In this case, one could analyze various types of public discourse and show that expanded moral consciousness is increasingly rooted in various forms of political and social discourse. ${ }^{10}$

\section{Universal history and the nature of reason}

"Under the government of reason our cognitions cannot at all constitute a rhapsody but must constitute a system, in which alone they can support and advance its essential ends" ( $\mathrm{KrV}$, B 860). For Kant, reason is essentially systematic, in the sense that its various faculties and operations are organized to sustain and promote its purposes. Reason is seen as an organic system in which several faculties interact in order to produce representations. Firstly, in an organism "it is requisite that its parts (as far as their existence and their form are concerned) are possible only through their relation to the whole" (KU, AA 05: 373. 04-06). This means that each faculty must act to promote the functioning and the ends of the whole. In this case, for instance, the possibility of representing an object as such depends on the joint efforts of the faculty of

10 Kant does so when he exposes the sophistic maxims of the political moralist and when he states that "people can no more get away from the concept of right in their private relations than in their public relations, and they dare not openly base politics merely on the machinations of prudence and so disown all allegiance to the concept of a public right" (ZeF, AA 08: 375f.). The same happens in relation to the concept of "right" in international relations (Cf. ZeF, AA 08: 355). 
sensibility and understanding. In a similar fashion, the symbolic representation of good God depends on three things: the limitation of objective knowledge; the transfer of symbolic empirical content to a transcendental concept; and finally, a practical need legitimated from the context of pure practical reason. In other words, anything produced by reason arises in isolation or without regard to a coordinated use of faculties. Even the theory of the factum of reason is understood only through the limits that the action of one faculty imposes on the other, to the extent that the action of different faculties is simultaneously restricted and coordinated.

However, if only this first criterion were met, then reason would be like a clock, where "one wheel is not the efficient cause for the production of the other: one part is certainly present for the sake of the other but not because of it" (KU, AA 05: 374. 09-11). So, an organically conceived reason must also fulfill a second criterion, namely, each part must be "conceived as if it exists only through all the others, thus as if existing for the sake of the others and on account of the whole". This means that each part "must be thought of as an organ that produces the other parts (consequently each produces the others reciprocally)" (KU, AA 05: 373. 17-19). There is no doubt that Kant understands reason in this way. He speaks several times about the relationship between faculties ${ }^{11}$, as, for example, when he proposes that sensitivity and understanding might spring from a common root in the hidden depths of the soul (cf. $\mathrm{KrV}, \mathrm{B}$ 29). However, this cannot provide an objective and definitive proof that reason functions as an organism. Yet, the fact that reason produces inevitable illusions is a strong argument in its favor. It would be hard to think of a reason that was merely an interconnected network of several distinct operations that mutually restricted each other. Such a reason would not be likely to fall into confusion and create new representations (cf. Henrich, 1989, p. 46). When a complex cognitive machine such as a computer breaks down, that is, when its operations (programs) collide or mistakenly mingle, it does not create a new and entirely different program from this clash. It simply locks up. Therefore, the creation of illusions that can be contained but never "deleted" is a reflection of various operations of pure reason arising and functioning as an organized whole.

In the same way that one represents the system of pure reason as having an end, it is also possible to represent human history as tending to an end (cf.

11 Cf. "the nature of a pure speculative reason, which contains a truly articulated structure of members in which each thing is an organ, that is, in which everything is for the sake of each member, and each individual member is for the sake of all, so that even the least frailty, whether it be a mistake (an error) or a lack, must inevitably betray itself in its use" (KrV, B XXXVII-XXXVIII). 
$E a D$, AA 08: 331. 01-05). In the idea of the actualization of the highest good in the world, a justification can be found for assigning some value to human existence. In other words, it establishes a horizon under which one can produce a rational discourse capable of articulating freedom and nature.

However, the link between nature and freedom seems to produce a historical antinomy (cf. FM, AA 20: 306f. 35-08). But if theoretical reason cannot establish the link between the moral law and history, it does not mean that reason cannot and should not give any answer. Reason has a natural and inevitable interest in the possibility of the highest good in the world. Therefore, "if it is disputed that reason deserves the right to speak first in matters concerning supersensible objects such as the existence of God and the future world, then a wide gate is opened to all enthusiasm, superstition and even to atheism" (WDO, AA 08: 143. 07-10. See also, KpV, AA 05:135f.). Thus, from the very practical-systematic need of reason arises practical-dogmatic principles (cf. FM, AA 20: 307. 1923). Therefore, this historical antinomy is overcome using the foundation of the doctrine of transcendental idealism. It can make several distinctions, firstly into phenomena and noumena and next between the theoretical and practical use of reason. A final distinction is that between a practical use of reason, in a strict sense (which we call here as moral consciousness in a strict sense), and a dogmatic, practical one (or using the nomenclature advocated here: an expanded practical consciousness which is grounded in a systematic-practicalregulative use of reason).

This practical dogmatic use of reason, which we are calling here as a practical regulative reflection that produces a moral image of the world is the counterpart o the unity of reason as a result of the expanded moral consciousness. For this reason, this moral image "can, to be sure, grow internally (per intus susceptionem) but not externally (per appositionem), like an animal's body whose growth does not add a limb but rather makes each limb stronger and fitter for its end without any alteration of proportion" ( $K r V$, B 861). From the point of view of a critique of pure reason, a reason's organic growth means eliminating errors that erode the limits that guarantee the legitimacy of certain discourses. These limits ensure as well the he legitimacy of different types of rational discourse to the extent that they are inherent to rationality. In this sense, "if human nature is called to strive for the highest good, it must also be assumed that the measure of its cognitive faculties, especially their relation to one another, is suitable to this end" (KpV, AA 05: 146. 17-20). However, this aspiration of legitimacy cannot be claimed internally from any specific domain of an objective discourse, whether theoretical or practical, because, in one hand, ordering something that is not completely in our power is absurd, and, on the 
other hand, a theoretical knowledge of the possibility of the highest good would destroy both the limits of knowledge as well the moral value of actions, "hence most actions conforming to the law would be done from fear, only a few from hope, and none at all from duty" (KpV, AA 05: 147. 18-19).

A genealogic study of reason, as an organized whole, cannot offer logicaldeductive arguments. Yet, in the final analysis, the transcendental deduction is also a holistic one, which is proven by its own capacity to solve illusions and integrate discourses inherent to reason into a moral image of the world. ${ }^{12}$ This holistic argumentation that differentiates philosophical argumentation from mathematical reasoning should be assessed differently, and for the deduction of a synthetic principle a priori, "muß der Philosoph das gantze seiner Wissenschaft übersehen, um jeden Satz in Verhaltnis auf alle zu beurtheilen und ihm alsdenn seinen wahren Werth zu bestimmen" (Refl. 2513, AA 16: 400. 07-09). Thus, the critical-transcendental philosophy aims to build rational discourse based on totality, as is the case of a moral image of the world, but it does so without compromising the grounds of transcendental philosophy.

Thus, the very systematic possibility of a universal history is an effect of the systematic unity of reason, which, in turn, can only be represented in this way in so far as it is based on the justification of the idea of a universal history. This apparent circularity is actually a holistic reasoning. ${ }^{13}$ The idea of a universal history is legitimate insofar as it points to a legitimating fact (namely, the need of pure practical reason, which is a priori need of pure practical reason), but also because it produces a rational discourse that articulates with all other discourses of pure reason so that the whole is represented in a moral image of the world. This moral image, which depends of the idea of a universal history, is the condition that makes reason understand itself as a coherent unity. Using Henrich's terminology regarding the notion of deduction in Kant's philosophy, we could say that the universal history is a necessary condition of the possibility for the very unity of self-awareness of a being that knows and acts morally and coherently in a historical world (this last aspect will become clearer in the last section).

It is only if these arguments are correct that human history could be conceived of as belonging to the system of reason. Universal history is the condition of

12 Here Henrich's (1989) suggestion regarding the meaning and strategy of a transcendental deduction is followed.

13 Cf. "The philosophical argumentation must be holistic in the following sense: any result we arrive at must be checked against results that have been gained in other fields of philosophy. One cannot present philosophical insights without hesitation and separately from other proofs we are inclined to accept [...]. This stance explains Kant's claim that Critique becomes convincing only by virtue of the totality of its theorems and proofs" (Henrich, 1989, p. 41). 
possibility for representing the unity of expanded moral consciousness as having actual content and, ergo, for the representation of the unit of pure reason itself. In other words, the idea of universal history is not just an appendix to Kant's philosophical system, but its higher point. Without the idea of a universal history, reason would have systematical hints, but not a fully systematical point-of-view of its own discourses and, therefore, the organic unity of reason would not be rational thinkable, just "guessable".

\section{Final considerations: the moral image of the world and its political consequences}

A universal history that legitimizes hope for the moral progress of mankind also protects Kant's political theory from dogmatic theories such as that of political fatalism. Politics, understood "as doctrine of right put into practice" ( $\mathrm{ZeF}$, AA 08: 370), should be guided by moral principles which were set out in the Doctrine of law and based on the concept of duty. However, in the event of a demonstrable incapacity to perform one's duty, the rule of prudence that advises against attempting the unfeasible would take precedence over the moral commandment to act in order to promote moral progress (cf. TP, AA 08: 309). In this case there would be a collapse of reason, due to the contradiction between its theoretical and practical uses. However, as this is not the case, i.e., as one cannot demonstrate the impossibility of fulfilling one's duty, it can be concluded that the moral commandment takes precedence and therefore that that maxim of prudence does not apply. However, there is a distance between the duty to act for the moral progress of humanity and a universal history that incorporates the hope regarding progress. After all, from the duty comes the capacity, not the existence (cf. Allison, 1995, p. 46; Kleingeld, 1995, p. 55). In this case, a theory of history is not justified immediately and sufficiently from the concept of duty. So why does Kant not simply restrict himself to the thesis that human progress is possible, but go further, stating that we need to believe that such progress is in fact taking place?

As mentioned above, reason has the need to represent itself as rational, and therefore as systematic. This is the same as saying that pure reason has to present a satisfactory answer to the question of what we are allowed to hope for when individuals fulfill their duty, because it is a question that arises from pure reason itself (reason must answer the questions that arise from itself: cf. $\mathrm{KrV}$, B 791; see also $K r V$, B505). This question is grounded on an interest of pure reason, which, in turn, is the effect of the need of pure practical reason discussed above. The mere logical possibility of progress or its non-contradictoriness is not 
a satisfactory answer, because it would simply mean that it is not impossible to conceive it. However, further elements are necessary to enable a real possibility. In this sense, a theory must be built up that supports the real plausibility of moral progress and this, in turn, can only be based on a broad teleological theory of nature. In other words, ensuring the real or practical possibility of progress means coming up with a theory to explain why it makes sense to believe that progress has already been taking place. This is because a teleological theory of nature cannot just begin to operate at a particular historical moment, leaving all the past in a complete limbo of irrationality. Hence, ensuring the real possibility of human historical progress presupposes the construction of a theory that guarantees the rationality of the claim that progress is already taking place.

As a secondary reason, there is also the clash of two contrasting moral images of the world. On the one hand, the presumed higher faculty of knowledge, Law, on the other, the allegedly lower faculty, Philosophy. In The conflict of faculties, Kant takes up this issue which had already appeared in Theory and practice and Towards perpetual peace, namely, that Philosophy would present a theory that has no use in practice. Jurists and politicians reject the philosophical theory based on the concept of duty, because they see Philosophy as presenting a theory that assumes how men should be, while the actual practice must have a theory based on practice itself, i.e., a theory that is oriented to what men are (cf. ZeF, AA 08: 374. 01-08). In this sense, Kant utters a strong criticism against the "supposedly sagacious statesmen" ( $S F$, AA 07: 80. 14-23). Well, it is not accidentally that in The Conflict of faculties the dispute between Philosophy and Law returns as "an old question raised again: Is the human race constantly progressing?" The legitimacy of the belief in human progress is directly linked to the question of the applicability of the Kantian doctrine of law, which constitutes politics in its true sense. The impossibility of this belief makes room for the emergence of abderitistic, terroristic or eudemonistic conceptions of history which would stand in direct opposition to Kant's political theory (Cf. $S F$, AA 07: 81-82). Therefore, for said theory to maintain its coherence within the system of reason, it needs to expand and incorporate a moral image of the world, from which it can politically and theoretically confront competing moral images of the world. Thus, moral consciousness needs to expand and develop a moral view of the world for itself. It needs to formulate a moral teleology manifested in the forms of a moral anthropology and of a universal history with a cosmopolitan aim. This new theory, with the status of a regulative practical knowledge, faces dogmatic considerations raised from Law and applied Politics, which call themselves the true owners of knowledge about human beings. Instead, Kant's philosophy of history advocates a critical conception of what 
men are: what they did to themselves throughout history, but also what they could have done and still can do to themselves in the future according to their faculties (Cf. Anth, AA 07: 321).

The moral image of the world that emerges from an expanded moral consciousness allows us to think up new aspects of the relationship between what the world is and how it should be. If a theory is right, then it should not be dismissed because it is of no direct use. As Kant puts it: "it was not the fault of theory if it was of little use in practice, but rather of there having been not enough theory, which the man in question should have learned from experience and which is true theory even if he is not in a position to state it himself [...]" (TP, AA 08: 275. 25-27). So, in order to bridge the gap between theory and practice, Kant ponders on the intermediary faculty of judgment. In this specific case, the faculty of reflective judgment lets us build a practical teleological theory from which one can fill out the expanded moral consciousness with moral contents. Only thus can mankind achieve an understanding of its history and its nature. The practical teleological theory allows us to conceive the fulfilling of moral law and think the actualization of the highest good in the same moral image of the world. In other words, it is a practical teleological theory that allows us to think about the relationship between "how we and the world are" and "how they should be".

This is not about inventing some intermediate thing between right and utility such as "a pragmatically conditioned right", because "all politics must bend its knee before right" (ZeF, AA 08: 380. 34-37). Nor is it taking literally the said "fiat justitia, pereat mundus" and misinterpreting it "as permission to make use of one's own right with utmost rigor (which would conflict with ethical duty)" (ZeF, AA 08: 379. 02-04). What is at issue here is that political maxims should not be ruled by a concept of well-being or happiness of the state, but only by the principle of law. However, the application of this law needs political prudence and therefore a moral image of the world should not only enable it to simultaneously interpret empirical reality, but also to think about ways of obeying the law without subsequently destroying intention.

Thus, the very political theory and the theory of hope are articulated within a moral image of the world in order to resolve an inherent tension between the moral enlightenment project and the phenomenal reality. This integration occurs in two ways: dealing with the phenomenal contingency, on the one hand, and acting as a motivational element, on the other.

The belief that individual efforts for a greater good will be complemented by others is paramount to the meaning of human activity. The belief in progress aims to establish this horizon of meaning for political action, which the concept 
of duty by itself cannot guarantee in a sufficiently broad manner. This does not mean that duty ceases without hope, but in order to stay on its path without becoming a misanthrope, one needs to have a horizon of meaning that can only be created by the belief in the real possibility of the moral progress of humankind (cf. $K U$, AA 05: 452-453).

The theoretical status of universal history as a regulative practical knowledge or belief, understood in the technical sense, allows us to maintain the hope for a better future, without running the risk of relegating politics to fatalism or conformism. If the moral progress of humankind were theoretically determined, then why would we strive to achieve it? In other words, when one awaits rain or the turn of the seasons (which may be predicted according weather patterns), one would just conveniently expect the arrival of progress. On the other hand, the belief in the impossibility of progress also undermines all efforts directed towards it. To enable progress to occur as a specific human activity, we need to believe that it is possible. More than that, we must believe that it can be maintained as an intercultural and intergenerational project. This, in turn, is only possible if we assume that the human species is not averse to a moral destination and, therefore, that it is possible to have something like a moral teleology from which one can conceive of a universal history and a moral anthropology. This is because this is the only way in which it is possible to create an expanded moral consciousness with contents and historical experiences that can be intersubjectively and historically shared. The very possibility of progress ends up depending on the existence of a moral image of the world that is shared by people, because only from that basis can one conceive that human beings are and will be working on promoting progress. On the other hand, it is only by working on the promotion of progress that we can achieve the right to hope that our own efforts are contributing in some way to the constant improvement of humankind. This mutual dependence on hope and progress is only possible because hope is understood as a specific rational taking-to-be-true (Führwahrhalten), which is different from theoretical and practical knowledge.

Universal history sustains a moral image of the world in which human beings neither attribute the evils of their suffering to a providence nor to a fate in favor of a good future. That would be a cowardly attempt to escape responsibility for their current condition. It is in this sense that one must interpret the statements of Kant, that "it is of the greatest importance to be content with providence" (MAM, AA 08: 121. 02-09). Kant's criticism of political moralists and soothsayers in general is not restricted to the issue that their moral image of the world is wrong, but especially, because they believe in it. They act 'just to do what is necessary to producing it' (cf. SF, AA 07: 80). For this reason, 
hope in progress needs to be presupposed when one considers the institutional course of action that, in the long-term, may gradually incorporate the ideals of democracy and enlightenment, which, in turn, are the foundations of its own possibility. In other words, a pessimistic view of human history would, according to Kant, lead to a very different organization of political institutions, which, in turn, would be the main cause behind the very failure of the actualization of the ideals of Enlightenment. Therefore, political moralists "do not deserve a hearing, especially since such a pernicious theory itself produces the trouble it predicts, throwing human beings into one class with other living machines, which need only be aware that they are not free in order to become, in their own judgment, the most miserable of all beings in the world" ( $\mathrm{ZeF}$, AA 08: 378. 28-31). That way, "if it is a duty to realize the condition of public right, even if only in approximation by unending progress, and if there is also a wellfounded hope of this, then the perpetual peace that follows upon what have till now been falsely called peace treaties (strictly speaking, truces) is no empty idea but a task [Aufgabe] [...]" (ZeF, AA 08: 386. 27-31). This task clearly indicates a practical intentionality that presents the idea of a universal history as a moral image of the world that systematically originates from pure reason.

Moral teleology is established in the field of politics as a long and continuous process, but not a linear one. This does not mean that all ages are continuously and successively closer to the idea of law and moral progress than the previous age. Rather, it suggests that humankind, since it produces an expanded moral consciousness, need not start anew every time it strives to achieve a political project. The human species can consider the experiences of past generations as their own experiences (both in relation to errors and successes), after all that "requires correct concepts of the nature of a possible constitution, great experience practiced through many courses of life and beyond this a good will that is prepared to accept it" (IaG, AA 08: 23. 26-28). Even if it is not possible to feel a certain indignation when contemplating the confusion of human history on the big world stage (cf. $I a G$, AA 08: 17f.) and "even if the revolution or reform of a national constitution should finally miscarry, or, after some time had elapsed, everything should relapse into its former rut (as politicians now predict), that philosophical prophecy still would lose nothing of its force" ( $S F$, AA 07: 88. 20-24). Even if there are stops and setbacks "I predict its progress toward the better which, from now on, turns out to be no longer completely retrogressive. For such a phenomenon in human history will not be forgotten, because it has revealed a tendency and faculty in human nature for improvement [...]" (SF, AA 07: 88. 10-13). This impossibility of being forgotten is a reflection of an "expanded and collective moral consciousness" which gradually becomes 
real and self-conscious as a universal history articulates the morally relevant experiences of the human species in a discourse or as a content that is part of a moral image of the world. Said history, in turn, integrates both the objectivity of scientific knowledge and morality, as well as the achievements and political failures that make up human history.

After all, "such a justification of nature - or better, of providence - is no unimportant motive for choosing a particular viewpoint for considering the world" (IaG, AA 08. 30. 20-21). Representing, as does Mendelssohn, the human species as doomed to the rock of Sisyphus (where "the human race as a whole make small oscillations, and it never takes a few steps forward without soon afterward sliding back twice as fast into its former state.' ([...] in this way one takes the earth, as the Indians do, as a place of atonement for ancient sins that can now no longer be remembered.)" (TP, AA 08: 307. 27-30) implies denying any possibility of "loving" humankind, even if "not exactly so as to inflict troubles upon us but still so as to have as little as possible to do with him" (TP, AA 08: 307. 20-21). Summing up, the idea of a universal history can cope with the prospect that the human condition in history is seen as the Hell described by Dante, whose portal read: "All hope abandon ye who enter here" (Alighieri, Canto III).

\section{References}

ALIGHIERI, D. "The divine comedy". Transl. Rev. H. F. Cary, M. A. Free on-line in: http://www.gutenberg.org/files/8789/8789-h/8789-h.htm\#link3.

ALLISON, H. "The gulf between nature and freedom and nature's guarantee of perpetual peace". In: Eighth international Kant-congress, 1995. Milwaukee: Marquette University Press, 1995. Vol.1, pp. 37-49.

BECK, L. W. "A commentary on Kant's Critique of practical reason”. London/Chicago: University of Chicago Press, 1960.

DÜSING, K. "Das Problem des höchstens Gutes in Kants praktischer Philosophie". Kant-Studien, Nr. 62, pp. 5-42, 1971.

. "Die Teleologie in Kants Weltbegriff". Bonn: H. Bouvier, 1968.

GUYER, P. "Kant on freedom, law, and happiness". Cambridge: University Press, 2000. HENRICH, D. "The moral image of the world". In: . Aesthtic judgment and the moral image of the world. Standford: Standford University Press, 1992. pp. 3-28.

"Kant's notion of a deduction and the methodological background of the first Critique”. In: E. Förster (ed.). Kant's transcendental deductions: the three Critiques and the Opus postumum. Standford: University Press, 1989. pp. 29-46.

KANT, I. "Gesammelte Schriften". Hrsg.: Bd. 1-22 Preussische Akademie der Wissenschaften, Bd. 23 Deutsche Akademie der Wissenschaften zu Berlin, ab Bd. 24 Akademie der Wissenschaften zu Göttingen. Berlin, $1900 \mathrm{ff}$. 
KANT, I. "The Cambridge Edition of the Works of Immanuel Kant". Paul Guyer and Allen W. Wood, General Editors. Cambridge: Cambridge University Press, 1992-. KLEIN, J. T. "Kant e a ideia de uma história universal”. São Paulo: Loyola, 2016a. . "The Highest Good and the Practical Regulative Knowledge in Kants Critique of Practical Reason". Con-Textos Kantianos: International Journal of Philosophy, Vol. 3, pp. 210-230, 2016b.

. "Sobre o significado e a legitimidade transcendental dos conceitos de precisão, interesse, esperança e crença na filosofia kantiana". Veritas (Porto Alegre), Vol. 59, pp. 143-173, 2014.

KLEINGELD, P. "Fortschritt und Vernunft: Zur Geschichtsphilosophie Kants". Würzburg: Köningshausen \& Neumann, 1995.

LEBRUN, G. "Uma escatologia para a moral". In: R. Terra (org.). Idéia de uma história universal de um ponto de vista cosmopolita. São Paulo: Brasiliense, 1986. pp. 75-101. SILBER, J. R. "Kant's conception of the highest good as immanent and transcendent". The Philosophical Review, Vol. 68, Nr. 4, pp. 469-492, 1959. 